\title{
The Moscow We All Seek: Performing the Role of Vershinin in Anton Chekhov's The Three Sisters
}

Richard Mugrage

Follow this and additional works at: https://researchrepository.wvu.edu/etd

\section{Recommended Citation}

Mugrage, Richard, "The Moscow We All Seek: Performing the Role of Vershinin in Anton Chekhov's The Three Sisters" (2018). Graduate Theses, Dissertations, and Problem Reports. 6276.

https://researchrepository.wvu.edu/etd/6276

This Thesis is protected by copyright and/or related rights. It has been brought to you by the The Research Repository @ WVU with permission from the rights-holder(s). You are free to use this Thesis in any way that is permitted by the copyright and related rights legislation that applies to your use. For other uses you must obtain permission from the rights-holder(s) directly, unless additional rights are indicated by a Creative Commons license in the record and/ or on the work itself. This Thesis has been accepted for inclusion in WVU Graduate Theses, Dissertations, and Problem Reports collection by an authorized administrator of The Research Repository @ WVU. For more information, please contact researchrepository@mail.wvu.edu. 
The Moscow We All Seek:

Performing the Role of Vershinin in Anton Chekhov's

The Three Sisters

Rick Mugrage

Thesis submitted to the College of Creative Arts at

West Virginia University

in partial fulfillment of the requirements for the degree of

\author{
Master of Fine Arts \\ in \\ Acting
}

Lee Blair, M.F.A., Chair

Gerald McGonigle, M.F.A.

Jessica Morgan-Bishop, M.F.A.

School of Theatre \& Dance

Morgantown, West Virginia

2018

Keywords: acting techniques, Chekhov, Russia, military, imagination

Copyright 2018 Rick Mugrage 


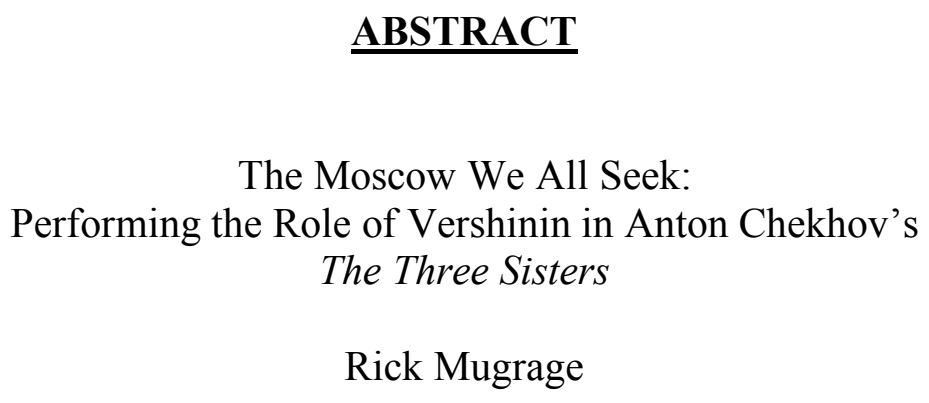

In this document, I will give a detailed account of my preparation, rehearsal and performance process, and finally, will evaluate and assess the outcome of my contributions and experiences as I performed the role of Vershinin in Anton Chekhov's The Three Sisters. Throughout the duration of this production, I was challenged and also rewarded by my struggles and discoveries while creating a complex character for the stage. The preparation for my role in the play consisted of using different acting techniques that I studied while at West Virginia University as well as research I compiled about life in Russia during the late 1800's, early 1900's. 


\section{ACKNOWLEDGEMENTS}

I would like to thank all of the people who have inspired me and contributed to to my education here at WVU and my life as an actor.

Jerry McGonigle, man...thank you for choosing me. Thank you for teaching me to dig deeper than I ever have. You were all I knew about the program before I signed up, and it was enough. Your genuineness, your commitment to the process of imagination, and your ability to paint a vivid mental landscape to help actors latch on to a sense of truth is something I will never forget. Thanks to you and Teresa for being willing to spend time and invest in our family. I'm forever indebted to your kindness and generosity.

Lee Blair, working with you has been a great privilege. You just get comedy. You get people. You call things like they are. I'm so thankful for your work ethic and your attention to detail in everything you do. Thank you not only for being a wonderful professor in the classroom but a relatable friend. You inspire me and make me want to be better. You make me believe I can succeed. That is one of the greatest gifts I've received here.

Laura Hitt, I've said this before, but I'm excited to write it down: you care. You genuinely care for students. That care and your selfless spirit paved the way in the classroom and allowed us to learn freely. The voice; such a powerful thing that so many people take for granted. Thank you for helping me be more free. My time with you has been such a joy.

Jessica Morgan Bishop, you taught me that I can challenge myself and break out of old patterns and habits. You were always right there with us in class doing the exercises you taught. You have been a support and advocate for all of us at one time or another. Thank you for your 
dedication and professionalism. You were always there to keep us grounded and focused.

Cathy O’Dell, you have a way of explaining different acting techniques and ideas that allow people to actually feel and see exactly what they need to when preparing for a role or doing an exercise. Thank you for being someone who listens and genuinely helps. I'm so thankful and blessed to have gotten the opportunity to work with you and learn from you.

Evie, you are my rock. You are my better half. You absolutely know the Jekyll and Hyde of me. You have been such a trooper and a rockstar throughout this whole program. Thank you for being my home. Thank you for making our home. I see you. I'm so proud of you. Thank you for believing in me and allowing me to do this. I'd be lost without you. I'd choose you again and again, always.

My kiddos, I love you guys so much. Thank you for helping me get through this. Coming home to you guys and being with you guys was what kept me going. I'm so thankful for you all. I'm so proud of you all. Thank you for loving me my family. Thank you for believing in me and going on all of my hair-brained adventures. You guys are my everything. You've all made me the richest man in the world. 


\section{TABLE OF CONTENTS}

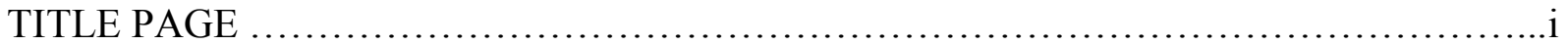

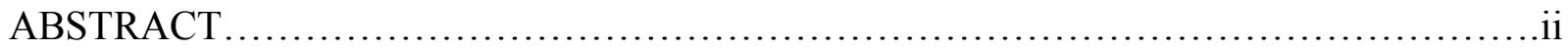

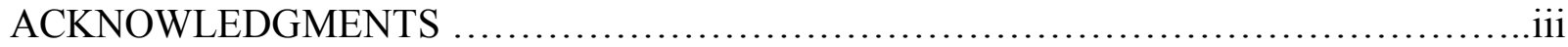

TABLE OF CONTENTS …................................................................

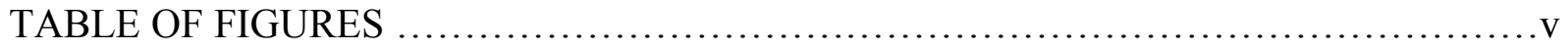

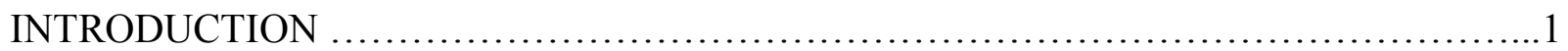

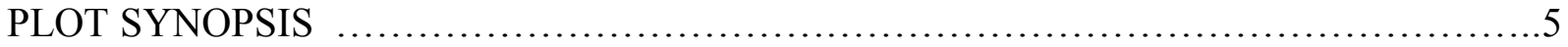

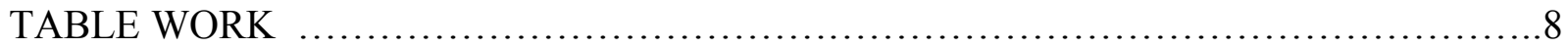

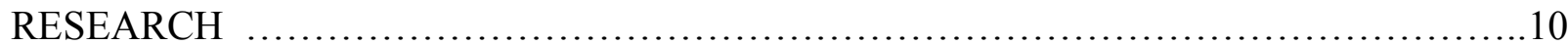

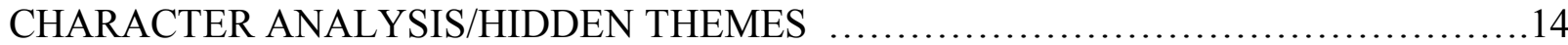

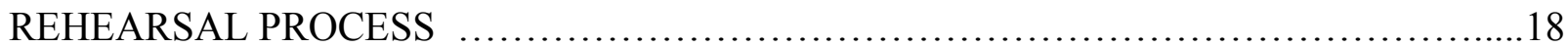

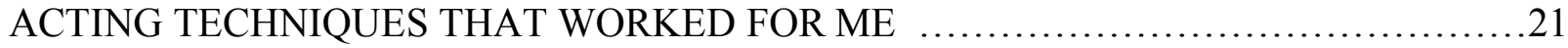

SET DESIGN AND CONCEPT/TECHNICAL ELEMENTS ...............................25

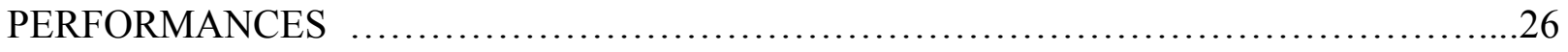

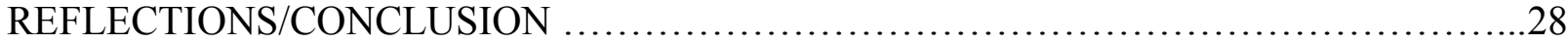

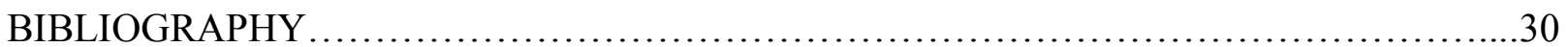




\section{TABLE OF FIGURES}

Figure 1 Set building/construction with designer James Raymond

Figure 2 Character beard application for Vershinnin

Figure 3 Gerald McGonigle giving specific instructions to stage hands

Figure 4 Director Gerald McGonigle on set

Figure 5 From left to right: Josh Short (Fedotik), Rick Mugrage (Vershinnin), Ian

Callahan (Solyony) and Mack Kale (Tuzenbach)

Figure 6 From left to right: Rick Mugrage (Vershinnin), Adam Demopoulos (Kulygin), Ian Callahan (Solyony)

Figure 7 Bench seat on stage Act IV

Figure 8 From left to right: Cassandra Hackbart (Masha), Jordan Crow (Irina) and Elise Rucker (Olga)

Figure 9 Michael Chekhov's chart for inspired acting

Figure 10 Upstairs bedroom Act III

Figure 11 Outside stairway to the backyard Act IV 


\section{INTRODUCTION}

I want to preface this whole thing by saying that I am so thankful for my time as a graduate student at WVU and the Studio Acting Program. Throughout the last three years, I have grown exponentially as an actor as well as someone who can operate under a high amount of stress. I came into grad school knowing that it would be extremely tough. My family and I have not only endured this program, we have come out on the other side having achieved what we set out to do. I think I can proudly say that if $I$ can do it, being married with six kids, almost anyone can.

When I began my journey at WVU, what stood out to me the most was the faculty's dedication to being on the same page in wanting each student to succeed. I was impressed to find that the program adopted a conservatory approach to scene study, monologue work, voice, movement, and textual analysis.

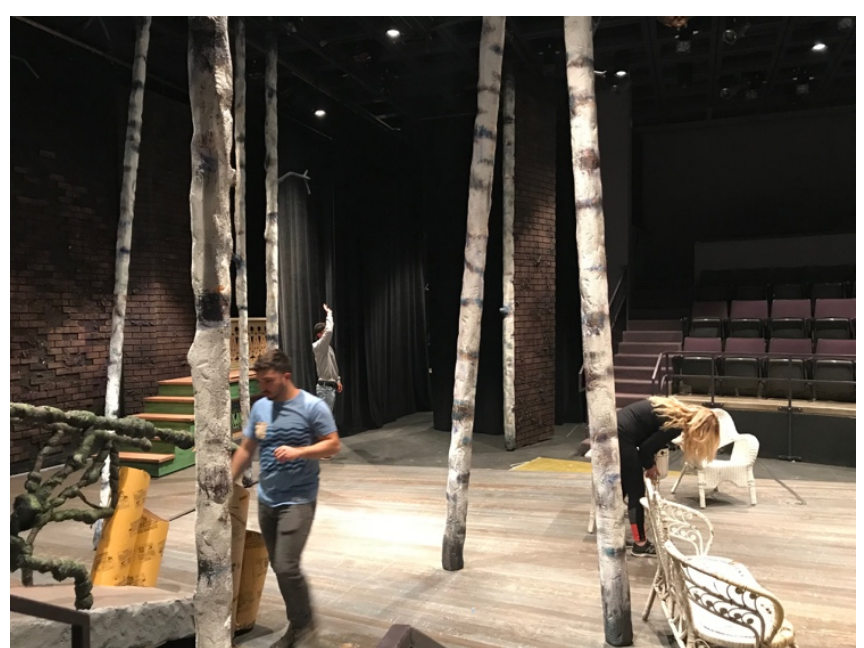

Figure 1 Set building/construction with designer James Raymond

Every Friday, either the graduate class or the undergraduate class would present scenes or monologues in front of the program faculty and the rest of the acting department. Essentially, we would have a couple of weeks to work on material that corresponded with the era or genre we were studying that particular semester.

Before coming to WVU, I had obviously performed quite a bit, but I had never performed on a regular basis in front of my fellow classmates and entire program faculty. In my 
opinion, this setting would prove to be one of the most beneficial things about the program.

As students of acting, I think we're good at playing the game. It's easy for us to act like we're getting something out of what we're doing. It's easy for us to hide ourselves in the corner and bide our time until the classroom bell chimes. We know how to be safe. My time at WVU has shown me that great acting requires one to really break out of these ideals. I'm not saying that you have to be unsafe in the sense that you're going to inflict harm on yourself or your scene partner. What I mean is that we have to break out of ourselves; let the spotlight shine on us so we can discover where we're lacking. Maybe what I'm saying is that to be a great actor, one has to be completely brave. I've found that it's much easier for me to perform in front of large crowds than in front of people I know and see on a daily basis. The privilege of performing in Studio, in front of my peers and the Performance Faculty was a giant step in allowing myself to be brave and to learn to stand under the searchlight.

I was stretched and challenged in the roles I played while at WVU. During my time in the MFA program, I've had the privilege of performing in Kiss Me Kate, The Arabian Nights, David Mamet's Race, Romeo and Juliet, A Funny Thing Happened on the Way to the Forum, Pirates of Penzance, and most recently I completed my thesis role as Vershinin in The Three Sisters. Each one of the roles I played required me to put the training I was receiving to the test. It was a stretch in the sense that the people that were training me would be watching, evaluating and taking notes, but even more so because the amount of material I was learning, at such a rapid rate, required me to be completely invested, mentally and physically.

When I started my training at WVU, I knew that I was in the MFA Acting program and not a Musical Theatre program. When one looks at my current resume, it is easy to see that I 
have gravitated more towards musical theatre. Getting cast in Three Sisters as well as the other straight plays at WVU was more difficult for me because I am more comfortable singing onstage than just acting onstage. I was a touring musician for years, and in most instances, was always onstage with my guitar. As an actor, a lot of my time onstage has been as an actor-singer. In both instances, I have felt more safe being onstage with something to hide behind rather than being completely myself. My time at WVU has ultimately made me ask the question, "Who am I and how can I be me onstage?" Each of the classes in this program have not only answered that question; they have taught me what I wanted to learn.

As I've pondered what I've learned the most, how I've grown, and what the take-away from this program at WVU has been for me, it is clear in my mind that being able to be more myself onstage without self-imposed borders has been by far the most transformative thing. I'm proud to say that I have learned that self-awareness is worth its weight in gold. Having a faculty that embraces your artistry, the ability to see unhealthy patterns, and walk you through different methods to break out of those patterns is a gift. I learned that I could relax and trust each of my professors, knowing that their ultimate goal was to make me free as an actor. 


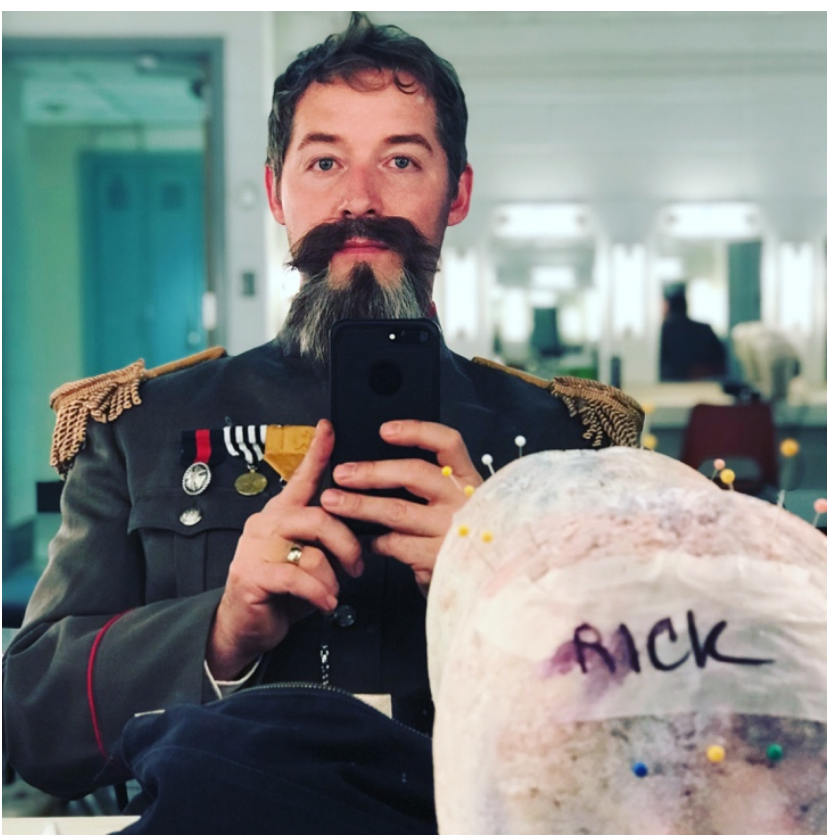

Figure 2 Character beard application for Vershinin 


\section{PLOT SYNOPSIS}

Anton Chekov's Three Sisters tells the story of four siblings struggling to make sense of their lives after the passing of their father. Set in a small Russian town, the play focuses on each character's desire to break out of their common provincial existence into something better. Having lived in Moscow, each of the characters continuously compare their current situation to what they once had or how they lived previously. The thought of Moscow becomes allegorical in the sense that it represents happiness and prosperity. Although every individual in the world of the play seeks a different position, status, or location, one theme runs throughout the story: they all seek Moscow.

Act One of The Three Sisters opens exactly one year after the death of Prosorov, the father of the three main characters: Olga, Masha, and Irina. Olga, the eldest of the sisters, is a school teacher who by the end of the play becomes a head mistress. Masha, the middle sister, is married to Kulygin. Married at only 18, Masha has become bored of her dull marriage and longs for excitement and romance. Irina, the youngest, has dreams of returning to Moscow to work and fall in love. Act One revolves around the idea that everything would be better if the family lived in Moscow again. These thoughts are amplified by the entrance of Vershinin, a soldier and old family friend who has recently arrived in town to take command of the military battery the sisters' father once commanded. His presence and arrival from Moscow is a breath of fresh air to the sisters, just as their youthfulness and excitement is to him. On the occasion of Irina's birthday, the sisters are throwing her a party and Vershinin joins the family and their friends for the evening festivities. By the end of the act, we know that Andrei, the sisters' brother, is in love with Natasha, a local girl who the sisters detest, Vershinin and Masha are both unhappy in their 
marriages, and moving to Moscow is the family's ultimate goal.

Act Two begins a year or more after Act One and we see that many relationships have been solidified. Andrei and Natasha have been married and have a child. Natasha is having an affair with a man we never see on stage named Protopopov. Tusenbach, a baron and regular at the house, is falling in love with Irina while Masha and Vershinin have also begun to fall in love with one another. By the end of this act, after a party erupts in the house and is quickly extinguished by Natasha, we see that any hope of happiness or joy the sisters may desire is contingent on Natasha's approval. Natasha has essentially become the master of the house and asserts herself in every possible way.

Act Three begins a year after Act Two as a fire ravages the town. Olga and the family work to help the victims of the fire. Vershinin and his family, displaced by the fire, take shelter at the sisters' house. Vershinin arrives at the sisters' house with Irina and Tusenbach and later makes known to Masha his feelings for her. As the act continues, it becomes clear that many in the house and around the town know that Natasha is having an affair. Masha tells her sisters of her feelings for Vershinin and her plans to be with him. Tusenbach previously proposes to Irina, and although she doesn't love him, she accepts the proposal and they plan to leave to work in Moscow.

The fourth and final act of the play takes place outside in the backyard of their home. The military battery is being transferred to Poland or Eastern Siberia. Soldiers and friends stop by to say their goodbyes to the family. Tensions are high as we discover that Solyony, a military soldier, frequent guest of their home, and admirer of Irina has challenged Tusenbach to a duel out of jealousy. Tusenbach, aware that he may meet his demise, professes his love and 
admiration once again to Irina. Andrei talks to long- time family friend and housemate Chebutykin about his relationship with his wife and makes it clear that he knows she is having an affair. Vershinin enters to say his goodbyes and apologizes to Olga for any trouble he may have caused. Masha and Vershinin have a long, heartfelt goodbye all while

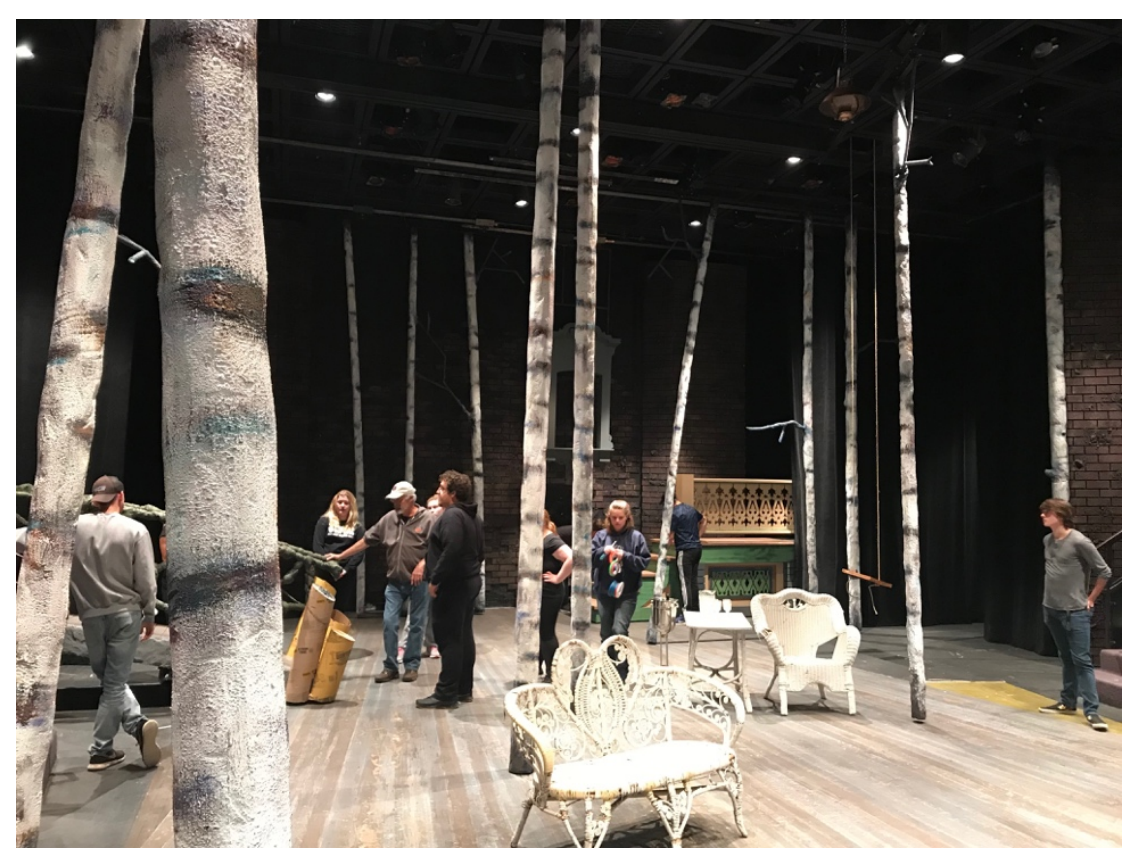

Figure 3 Professor McGonigle giving specific instructions to stage hands

Masha's husband Kulygin watches. Masha collapses, heartbroken after Vershinin leaves her, and Kulygin vows to her to forget about everything so they can move on. Chebutykin enters and whispers to Olga that Tusenbach has been fatally shot by Solyony. Irina, devastated and heartbroken is comforted by her sisters. The play ends with the sisters embracing each other, with Moscow now seemingly an unattainable dream. 


\section{TABLE WORK}

As we started our first rehearsals, we sat down and read the play as a cast twice. We discussed things like pronunciations, time and world of the play, and the different social statuses in Russia during that time. This initial dive into the text and the world of Three Sisters allowed me to start imagining things on my own, but also kept me anchored to the factual elements of the play. After our read-throughs and discussions, Prof. McGonigle, our director, focused the first two weeks of rehearsal on research and table work. This portion of the process was one of the

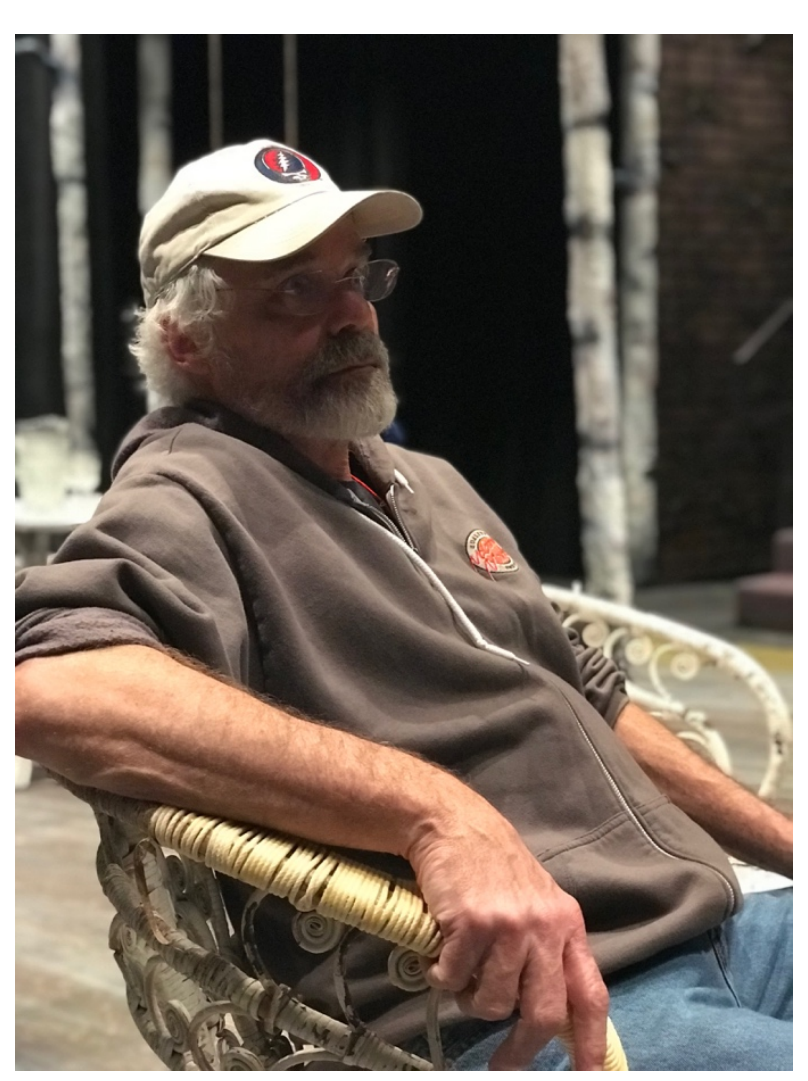

Figure 4 Director Gerald McGonigle on set best things that we did because it forced me to find information about my character. Everyone brought in research that pertained to their individual characters and their status within the play. We were each required to search for different topics such as military life in Russia, social status, standards of living and the economics of the time.

\section{Being that Vershinin was a military}

officer, I felt it important to seek out topics that involved the military and class system.

Throughout my time at WVU, I've found that asking myself questions as I research brings the most depth, not only in my actor's imagination, but also in the basic knowledge of the world of the play. What does it mean to be in the military during the early 1900's in Russia? How does the Russian military ranking system work? How 
does one become an officer in the Russian military? How much does a Russian officer make in a year? All of these questions, once answered, usually lead to more questions. Once the questions are answered, they enable me to create a living, truthful character.

During the table work process, the cast was very fortunate to have both Dr. Ganapathy as our dramaturg and Prof. Cathy O’Dell as our vocal coach. Having as many resources as possible to draw from, right from the beginning, allowed the cast to feel prepared and personally gave me the confidence to move forward in developing my character.

Our first two weeks of rehearsals consisted of learning about the world of the play during the era in which it was set. Prof. Ganapathy prepared PowerPoints in which she explained the differences between people from distinctive regions and classes. Once she gave us some of the basic information, Prof. McGonigle required each person in the cast to bring new information about life and times in Russia during the years the play was set into each table rehearsal. Prof. O'Dell helped us learn the different pronunciations of each of the characters' names, geographic locations, and all of the different items and terms mentioned in the show. 


\section{RESEARCH}

During the table work rehearsals, I was able to gather and retain a lot of information not only from my research but also from everyone else's research. Throughout the whole rehearsal process, the one resource that I turned to most was the book Daily Life in Russia under the Last Tsar by Henri Troyat especially for facts pertaining to military life in Russia. Prof. McGonigle required us to purchase Troyat's book our second year of school when we were studying Chekhov, and it proved to be an invaluable resource. Detailed information about the Russian military was not very easy to come by on the internet and I found it best to find my information from Troyat's publication.

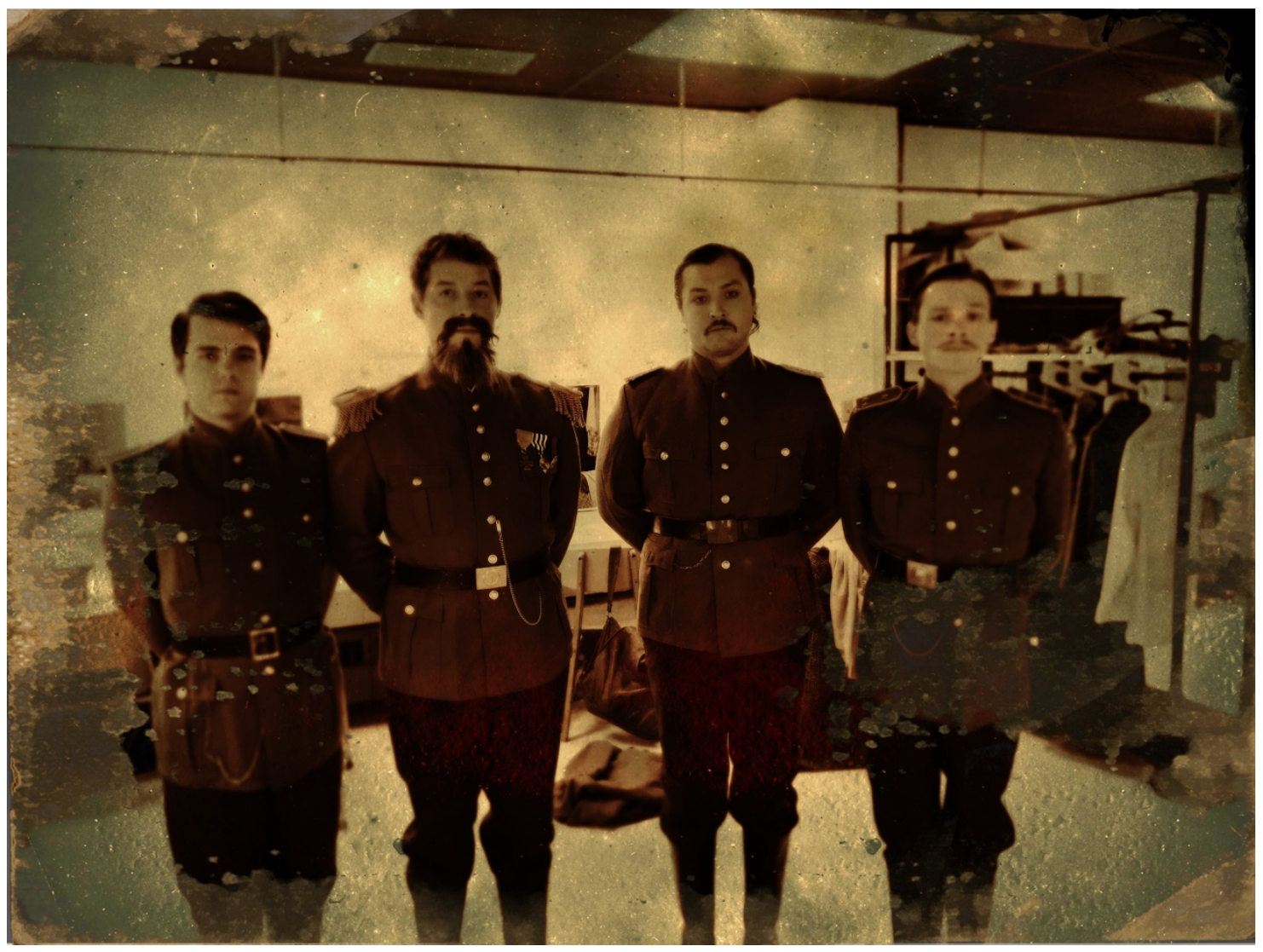

Figure 5 From left to right: Josh Short (Fedotik), Rick Mugrage (Vershinnin), Ian Callahan (Solyony) and Mack Kale (Tuzenbach) 
In Three Sisters, Vershinin is a lieutenant colonel. We know from the play that he has been assigned to command the military battery that the sisters' father commanded before his death:

Yes, that's right! When your father was a battery commander here, I was an officer in the same brigade. (Chekhov 8)

He also states:

Yes. I went to school in Moscow and began my service in Moscow. I served there for quite some time. But finally I have been assigned to command this battery and have moved here as you see. (Chekhov 8)

For Russians during the early to mid 1800's, becoming a soldier or not wasn't a choice they were allowed to make. It was mandatory before January 1st, 1874.

Before the law of January 1, 1874, military service was for twenty-five years for those who, selected by lot, had no means with which to buy themselves out or have themselves replaced. Once called to the colors, the man became more or less a military man for life. When returned to civilian life after twenty five years with the army, he remained a person apart, isolated, unadapted, no longer having the taste for the sort of life led by those around him. (Troyat 116)

After a law in 1874 regarding military selection was set in place, military service was still mandatory on a lottery basis, as well as compulsory depending on age.

Russel learned that since the reforms of 1874, military service was compulsory 
for everyone in Russia for twenty-one to forty-three years of age, without any possibility of buying out or substitution. The men passed as 'fit' were registered either in the ranks of the regular army, or in the territorial reserve. Active army service was for eighteen years, five of which were with the colors and thirteen with the reserve or militia. (Troyat 115)

After their initial five years of active service was finished, only the young men that were fit enough and called up by the lottery were placed into the regular army full-time. Those not called up by lottery remained on alert in case of war or attack in the reserves or militia.

\footnotetext{
Although military

service was mandatory,

there were clear

distinctions in rank and

class between the rich

and poor serving in the

military. Very similar to

the socio-economic

structures set in place

in civilian life, the rich

ranked higher in class and

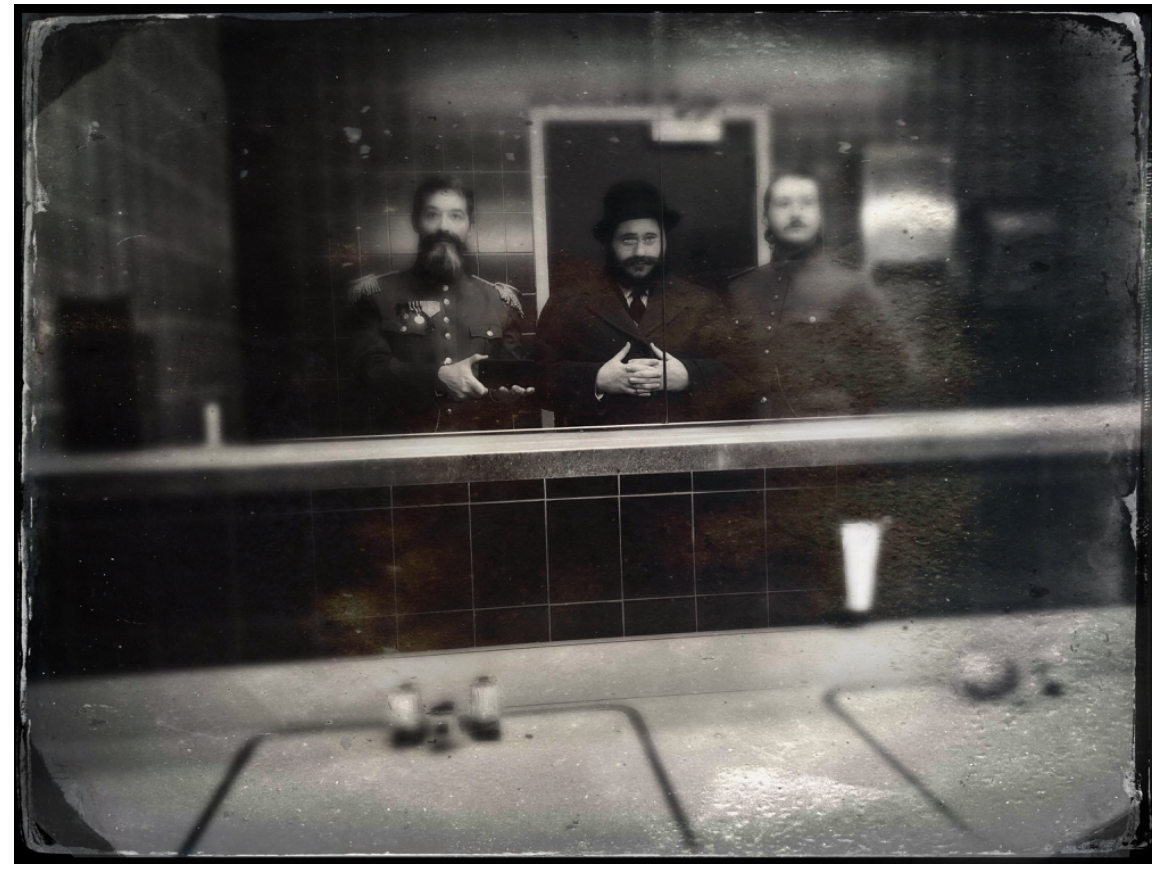

Figure 6 From left to right: Rick Mugrage (Vershinnin), Adam Demopoulos (Kulygin), Ian Callahan (Solyony)

had more opportunities to better themselves. As a lieutenant colonel, Vershinin would have had to have been from a family of nobility or in the aristocracy. Officer ranks were reserved for higher class citizens whereas the lower ranks and enlisted men were comprised of children of
} 
peasants:

For a boy to be admitted to this institution, not only did his father and grandfather have to have been incontestable nobility, but one or the other must have served in the Russian army with the rank of general. (Troyat 114)

That being said, the sisters and their brother Andrei would have been considered high society as their father was a ranking officer in the Russian military. It is likely that the family was taken care of financially by their father's military retirement pension which allowed them to retain a higher class status. In the play, we see that the sisters' house is frequented by many military officers. Officers in the army didn't fraternize with lower-class citizens so we can deduce that the sisters were in fact high-class socialites.

As an actor, finding out this kind information becomes a priceless when thinking about ways to create an emotional bond between characters. Vershinin and Masha are essentially born of the same cloth. When Vershinin walked into the sisters' house for the first time, he felt like he was home. He was reminded of his old boss in the military while being reminded of Moscow and the beginnings of his military service and education. Everything that he was experiencing was creating a sense of hope and new life. 


\section{CHARACTER ANALYSIS/HIDDEN THEMES}

\section{BASIC INFORMATION}

Full Name: Alexander Ignatiavich Vershinin

Gender: Male

Age: (Act I) 42 (End of play) 45

Occupation: Lieutenant Colonel

Marital Status: Married

Children: Two Daughters

Previous Marriages: One

PHYSICAL APPEARANCE

Height: 6' 2"

Weight: 205lbs

Hair Color: Brown

Facial Hair: Beard and Mustache

Eye Color: Green

\section{PERSONALITY}

Personality: Pensive, Quirky, Excitable, Melancholy, Jovial.

Likes: Philosophy and the idea of the world changing and bettering itself through progress.

Dislikes: Stagnant ideas, his relationship with his wife, getting older and not being able to achieve all he'd like to. 
When beginning a study of the character of Vershinin, there are a lot of obvious facts in the text that can be used by an actor. He's in the military. He's in his forties. Because of his rank, we know that he is privileged or comes from a privileged family. He's married and has two daughters from a previous marriage. We also know that he knows Colonel Prosorov's three daughters.

Very, very happy to see you again. But how you've grown up, changed! Well, I saw you there many times. But how time flies. How it flies. I used to visit you in Moscow. (Chekhov 8).

I think the less obvious or abstract attributes of the character of Vershinin are the most important. He is a man, saddened and depressed by his current marriage. Throughout the play, he makes it known to the sisters that he is indeed an unhappily married man.

Well, yes. When they called me the lovesick major, I was still young and of course I was in love then. Now unfortunately, that is not the case (Chekhov 9)

He blatantly states his unhappy feelings again and even goes on to say, “...If I were starting my life again, I wouldn't marry. No. I'm afraid I wouldn't. No.” (Chekhov 15)

From the moment Vershinin enters Prosorov's house and encounters the sisters, something awakens in him. He begins to come alive. He is reminded of a time before his current situation; before his current marriage. It was a time he was young and in love. The moments he refers to are when he was full of joy and hope was alive in him. Vershinin's relationship with his wife isn't a pleasant one. There are many blatant references throughout the text about this. His current wife is also not the mother of his two little girls: 
“...I get upset and feel guilty that they

have such a step mother. If you would

have seen her today. So ridiculous. At

seven this morning we began to quarrel,

and at nine, I walked out and I

slammed the door" (Chekhov 26)

Vershinin's desire for Masha and his relationship with her is born out of passion and excitement. He longs to feel love again. He needs it. It isn't until near the end of the story that Vershinin and Masha take the actual step of being together intimately. They find comfort in each other during a time in their lives when happiness seems lost. The relationship is doomed not to last because of each of their situations, but in the moment they just want to experience what they feel they're lacking in their everyday lives.

For the daughters, Moscow represents

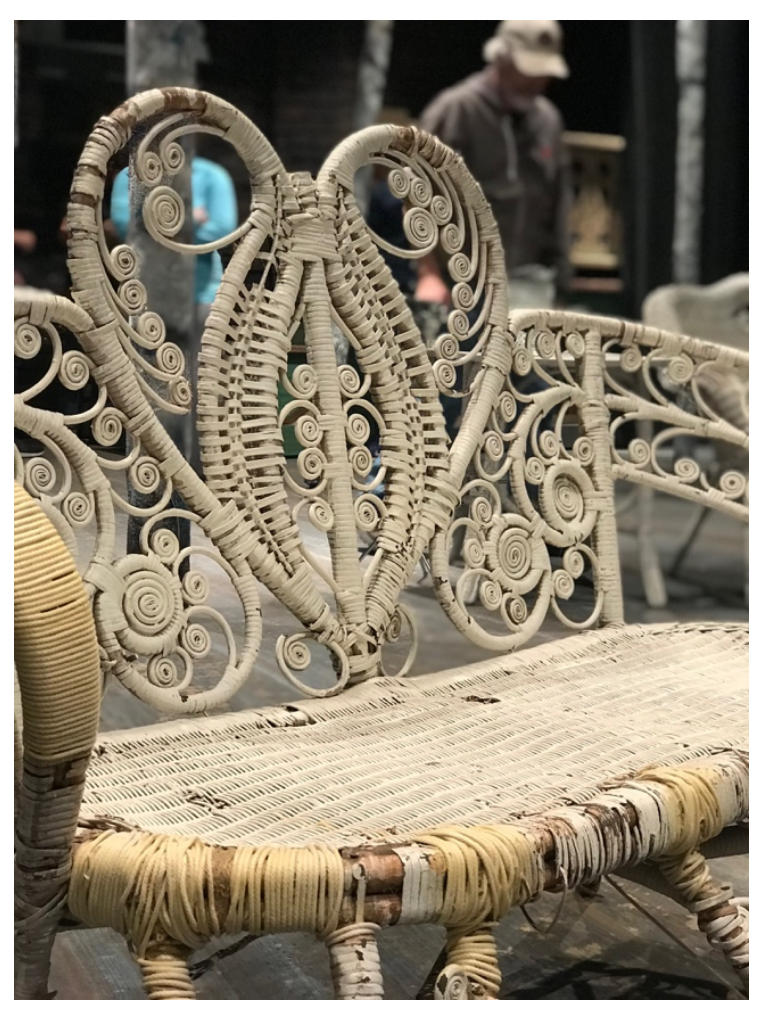

Figure 7 Bench seat on stage Act IV

all that they need to be happy and complete. Throughout the story, Moscow is continually referenced by each of the sisters as their source of hope for each of their futures. Vershinin, having recently left Moscow, finds solace and comfort in the surroundings in the sister's town:

No. Really? I think you've an excellent climate here. Invigorating. A real Russian 
climate. The forest, the river and of course the Birch trees. Lovely. Simply

Birches. My favorite trees. No, living here is really very pleasant. (Chekhov 10)

Each character in The Three Sisters is longing for their own Moscow. Vershinin's Moscow is the sisters. The sisters long for a time in which they remember being happy and full of joy. Vershinin longs for the same. Although each of the characters' desires throughout the play are somewhat different, they all long for the same thing essentially: to go back to a time when things were better. To each of them Moscow represents the good old days. It is reminiscent of a time when whole world was at each of their fingertips. It was a time in which life was untainted by death, despair and longing. Unfortunately, by the end of the story, Moscow becomes unattainable for everyone. Vershinin's military transfer to Siberia becomes a metaphor in which he is further away from Moscow than when he started. His goals, his passion, and his dreams have faded away and he has been exiled to a place that is cold and distant. 


\section{REHEARSAL PROCESS}

The Three Sisters was my third time working with our director Prof. McGonigle, the head of the Graduate Acting Program at WVU. I appreciate his ability to make rehearsals sacred. The theatre is a hallowed space where we as actors come to dream, imagine and live in the truth of the world of the play. Each show that I've had the opportunity of working with Jerry on has had its own unique factors and sets of challenges, but one thing always stays the same: it's about what is in the text of the play. I admire that about him. My time at WVU has solidified the idea of letting the writer speak through the text. Every word, every bit of punctuation, and each character was carefully thought about and planned while being penned by the playwright. Learning to honor that idea has been wonderful.

The rehearsal process for this show was very straightforward. When we were called to rehearse, we would show up, find a spot to warm up and go through our script, and then Prof. McGonigle would allow us time to simply live in the space. Being able to live in the space as an actor is one of the most important things we can do. It allows us to become familiar with the world of the play and deepens our imaginary investment in the story. I feel very fortunate that he is a director that fights to have set pieces and furniture brought out early in the process rather than later. Having the space set up allowed us to experiment within the confines of the set. As an actor, I've found that you shouldn't be worried about where or how you're going to sit or stand; you should just do it. If you're thinking about how you're going to walk or sit, you're basically just acting badly. As an actor, if I'm thinking about how I'm going to do something instead of just doing it naturally, then I'm overthinking and my acting becomes contrived. I say all of that to commend him and our production team for making it possible for us to get to utilize the set 
and props well before we had an audience. Being able to do so helped us to actually be at home in the space.

I really value Prof. McGonigle's approach to working a scene until each actor feels like they've gotten it right. He made adjustments in our rehearsal schedule to allow different

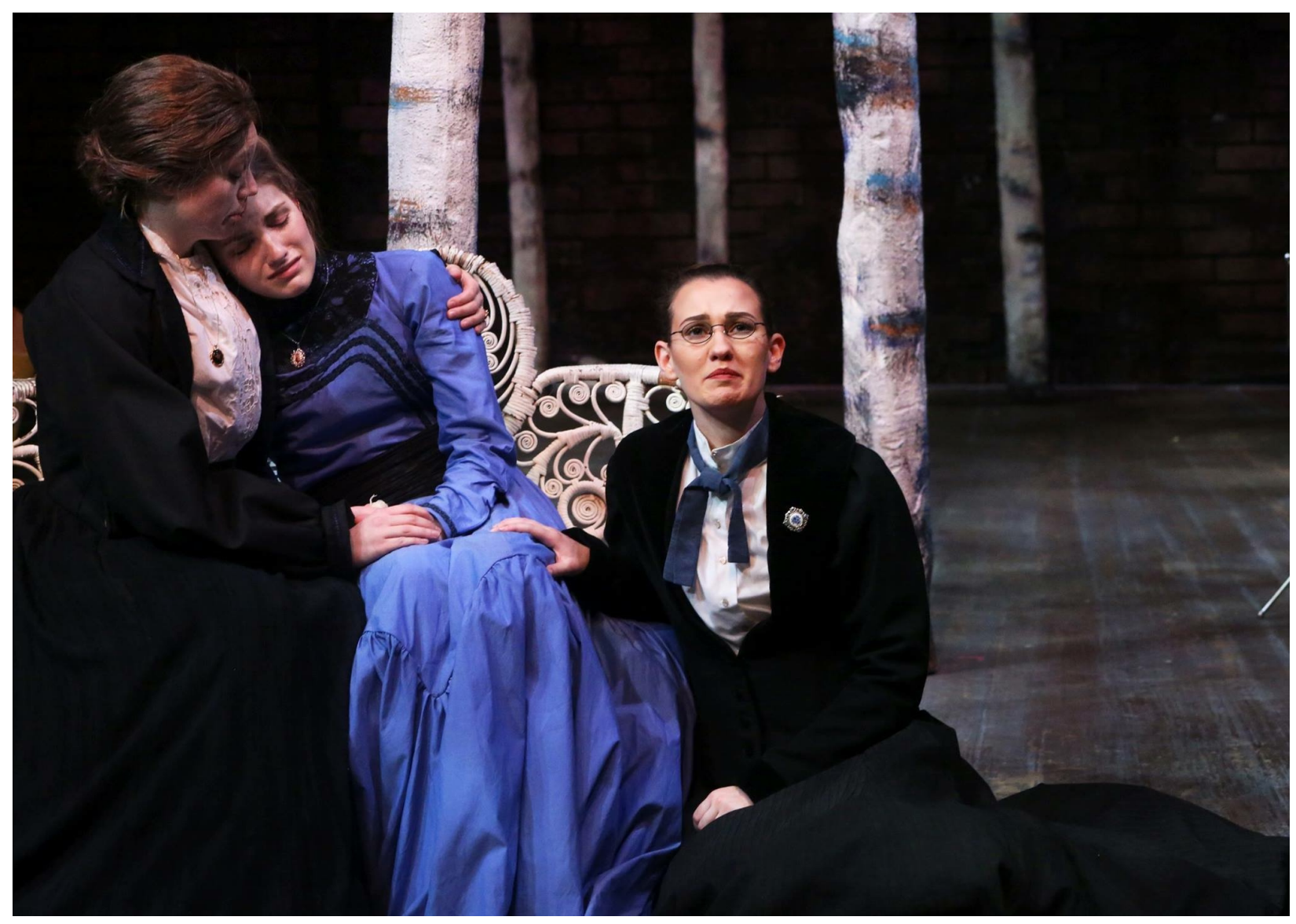

Figure 8 From left to right: Cassandra Hackbart (Masha), Jordan Crow (Irina) and Elise Rucker (Olga)

moments to take shape. When we first began the rehearsal process, I was really uncomfortable with playing the character of Vershinin. I didn't have a clear direction in my mind as to who I wanted him to be. A lot of the time as I prepare to take on a role, characters will present themselves to me, either as I read or just get on my feet and experiment with the way they might move or talk. As rehearsals progressed, I was having a very hard time becoming Vershinin. I just wasn't finding the character. The harder I tried, the more forced it all felt. One of the problems I 
was having was how to relate to the things Vershinin was saying. He's a very talkative character and genuinely believes everything that he says. I just couldn't make myself feel excited about any of the things he said or philosophized about. Prof. McGonigle talked me through my fears and frustrations and helped to make sense of the character for me.

He made time for things to be right. He explained to me that Vershinin is actually a quirky kind of a guy. He's a character. I didn't have to make him stoic or insincere. That input helped me tremendously. In the end, I connected with Vershinin's humanity. I found it easier to be myself as Vershinin the more I related to his relationship struggles and victories. In the end, it was all about realizing that the person I was playing was, in fact, a person. I didn't have to rely on a characterization or an idea of what I thought he should be. My biggest breakthrough came after I realized that I just needed to give myself permission to be me as the character. When I reached that place, it helped a lot.

As an actor, my job is to find meaning in whatever I'm performing. I strongly believe that being an actor should make a person more empathetic. One of the questions that I ask myself when I'm beginning to study any role is, "How am I similar, or how is my situation similar with this character?" I was fortunate in this show to be playing a character that was married and had kids. I was able to draw from my own life experiences to help bring Vershinin to life emotionally and physically onstage. Whenever I felt stuck or unsure of how to progress with the character of Vershinin, the similarities we shared became the waypoint for me to come back to, and helped me become grounded again. 


\section{ACTING TECHNIQUES THAT WORKED FOR ME}

During my time in the Graduate Acting Program at West Virginia University, I have had the opportunity of not only learn different acting techniques, I've also had the privilege of working with different professors who specialize these techniques. I can honestly say that the work that I do now as an actor, either onstage or on camera, utilizes a bit of each method that I've been taught. Some methods work better for me than others, but there isn't one of them that I don't draw from on a regular basis.

\section{MEISNER}

The Meisner method taught me to daydream about the circumstances surrounding each character I create. I'm able to draw from real experiences, as well as the hopes and dreams from my real life. Doing so gives me a deep concentrated connection with any character. When I can assimilate some of myself into a role and then bring specificity into it by joining my real life circumstances with the character's circumstances, I feel like I'm portraying an honest representation of who that character is supposed to be.

I have to research who I'm playing and then draw some sort of correlation between that character and myself. Then I daydream about my life in the world of the play. To be honest, it can be a bit exhausting. I'm not too proud to say that I have many short-comings. There were many nights during Three Sisters that I would come into the rehearsal space and be unable to put in $100 \%$ all of the time. I've found that if I strictly try to use Meisner, I need to save some of the daydreaming and emotional "polish" for actual shows. When I do that, I tend to make new discoveries each night and each moment feels brand new. 
Meisner has also made me a better listener as an actor and in my everyday life. Listening has helped me live from moment to moment onstage instead of cue to cue. I'm so thankful for this particular aspect of my training. I'm a fast-paced person who usually has a million things going on at once, so learning to slow down and take the time to listen is paramount.

\section{MICHAEL CHEKHOV}

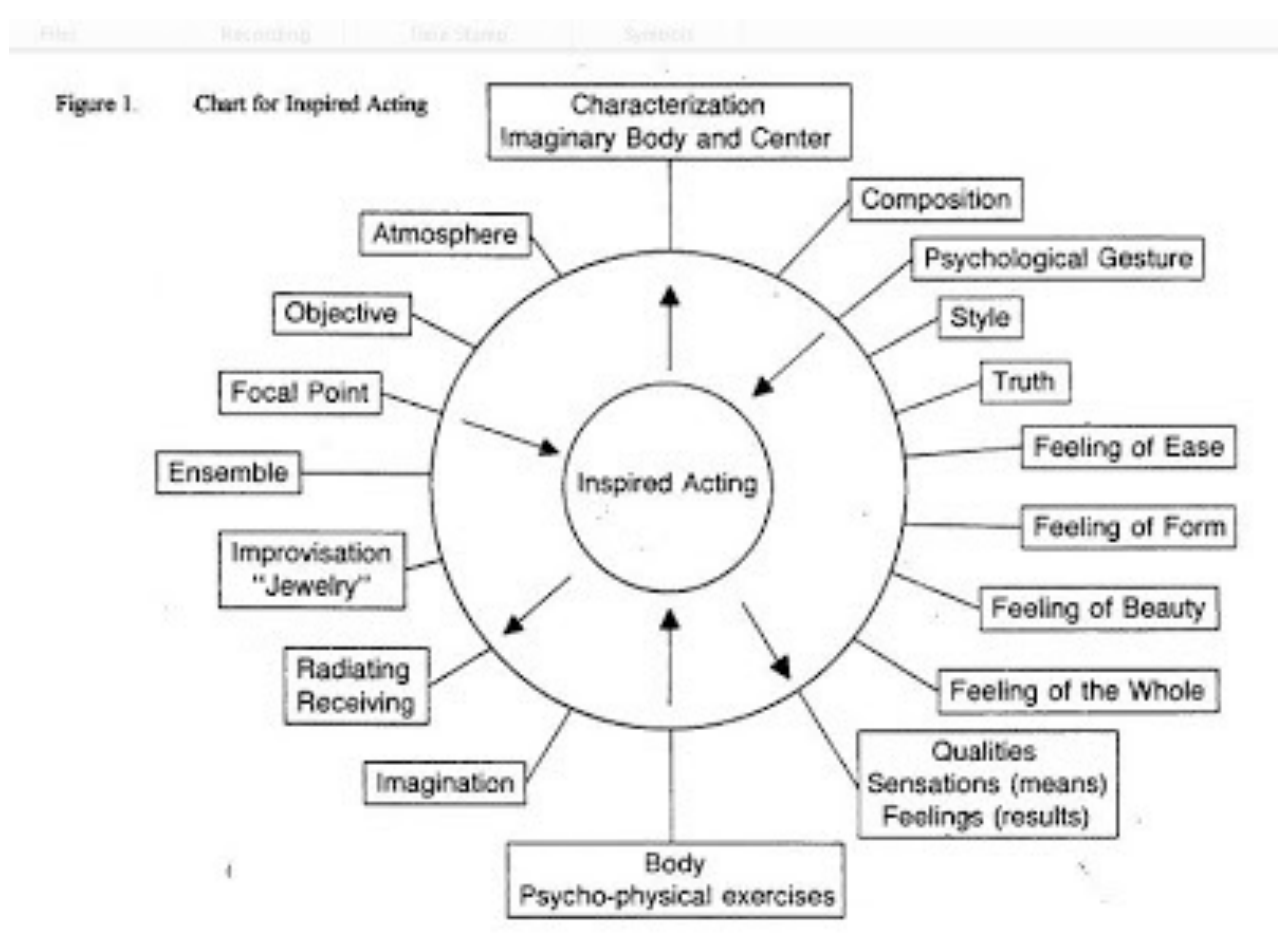

Figure 9 Michael Chekhov's chart for inspired acting

Chekov's external approach and use of psychological gestures was hard for me to grasp at first. As we learned more about the technique and experimented with different gestures, I began to understand that the Chekhov Method relies heavily on imagination. Chekhov uses physical gestures performed by the actor to express or create what is happening emotionally inside of the character. He also encourages the actor to imagine the surroundings and atmosphere of a room or place. The result in using this method is the feeling you get while practicing it. You get to experience feelings and emotions that can be inserted or transferred into different 
situations as you perform.

\section{VIEWPOINTS}

Created by choreographer Marie Overlie and adapted for stage acting by directors Anne Bogart and Tina Landau, Viewpoints is a movement-based acting tool that focuses on things that we as humans always do.

Over the years, we have simply articulated a set of names for things that already exist, things that we do naturally and have always done, with greater or lesser degrees of consciousness and emphasis. (Bogart and Landau 7)

I really enjoy Viewpoints. I've found it most useful in creating new work. It gives a performer the freedom to explore and create something they might not usually create, at least that is my experience. I've also found it to be a great method for ensemble work. It enables actors to come together to create and work off of each other's movements. What starts as simple movements and exploration soon becomes a story. The performer focuses on the way their body moves through space, the tempo it moves at, the shape it becomes, and the duration of how long the movements last.

With Viewpoints, I found a lot of release from tensions that I've held on to for a long time. I used to have a lot of stiffness in my back and neck. One of the reason was simply the way that I carry myself, but another was the way that I moved in performances. Without an experimentation, you will always be stuck in the same patterns. Viewpoints caused me to explore the way that I moved and interacted with my body. Essentially, I had to explore different ways of using my whole body. 
As I said before, I don't find any of these methods to be superior to the other. Imagining, listening, and letting your body be completely invested in whatever you're doing are, in my opinion, the keys to great acting. I think that all actors are different and each of them use the technique or techniques that allow them to commit to whatever role they're playing. I've found that most of these methods, when coupled with other methods, become much more potent. For example. If I use Meisner to inform my emotional life as an actor and allow my movements to be influenced by using Viewpoints, my performance should be deeper than just using one method. I respect and honor everyone of the methods that I've learned and look at them all as different tools in my actor toolbox. I like to equate it to working on a construction job. Sometimes certain jobs call for certain tools. Maybe I need a hammer for one. Other times, we may run into a job that needs requires the whole toolbox. I'd rather go into a situation with more than enough items to finish the job than just one. A hammer won't screw a screw into sheetrock. 


\section{SET DESIGN AND CONCEPT/TECHNICAL ELEMENTS}

The set design and production quality at WVU by far exceeds anywhere I've gone to school or worked. The commitment to perfection that everyone on the production team for this show exemplified is mind blowing. As I said before, being able to act on a set, weeks before a

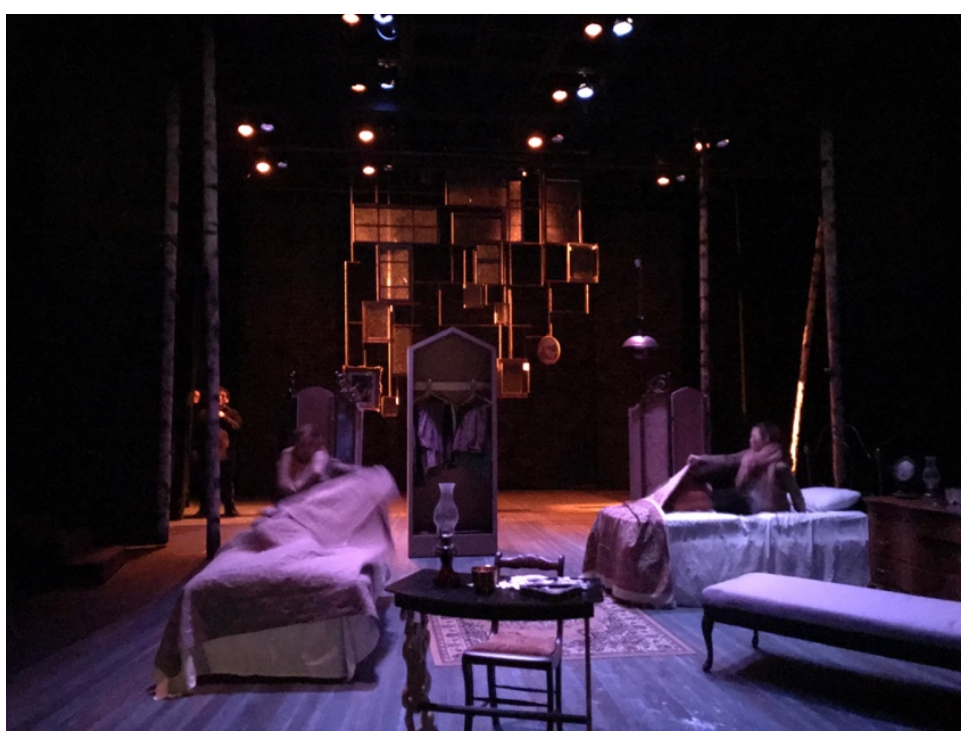

Figure 10 Upstairs bedroom Act III production's opening is phenomenal. In The Three Sisters, the show starts with a high sense of hope and ends tragically as the dreams of practically every character are snuffed out. I enjoyed how the physical space mirrored the emotional conflict of the show. Scenic designer James

trees continue to encroach on the playing space as the show went on was brilliant. Even before the set was complete, we were all presented with the complete renderings of the finished space. There wasn't ever a moment during the rehearsals of this show that I felt lost or couldn't imagine what the completed space would become. From the lighting to sound to scenic elements to costuming, the whole design and technical team worked as a true ensemble to create something magical. 


\section{PERFORMANCES}

Sometimes when working on a show, things come together at the exact last minute. I've performed in shows before when we didn't even have a set until a day before the production and the paint was literally still wet on opening night. This was not the case for this show. Once we opened the show, we were ready. We were prepared and spent many of our final rehearsals running the show and making small adjustments. In studying Anton Chekhov, one of the most important things I learned was to find the comedy in his writing. Chekhov basically wrote about people having droll, mundane, everyday experiences. Many people don't consider Chekov's work comedy but it truly is. Chekhov could have written in a scene right before Act Three opens. We could have heroically been running around on stage, putting out fires and saving children from burning houses. He chose to leave all that out and skipped right to the part where people sit

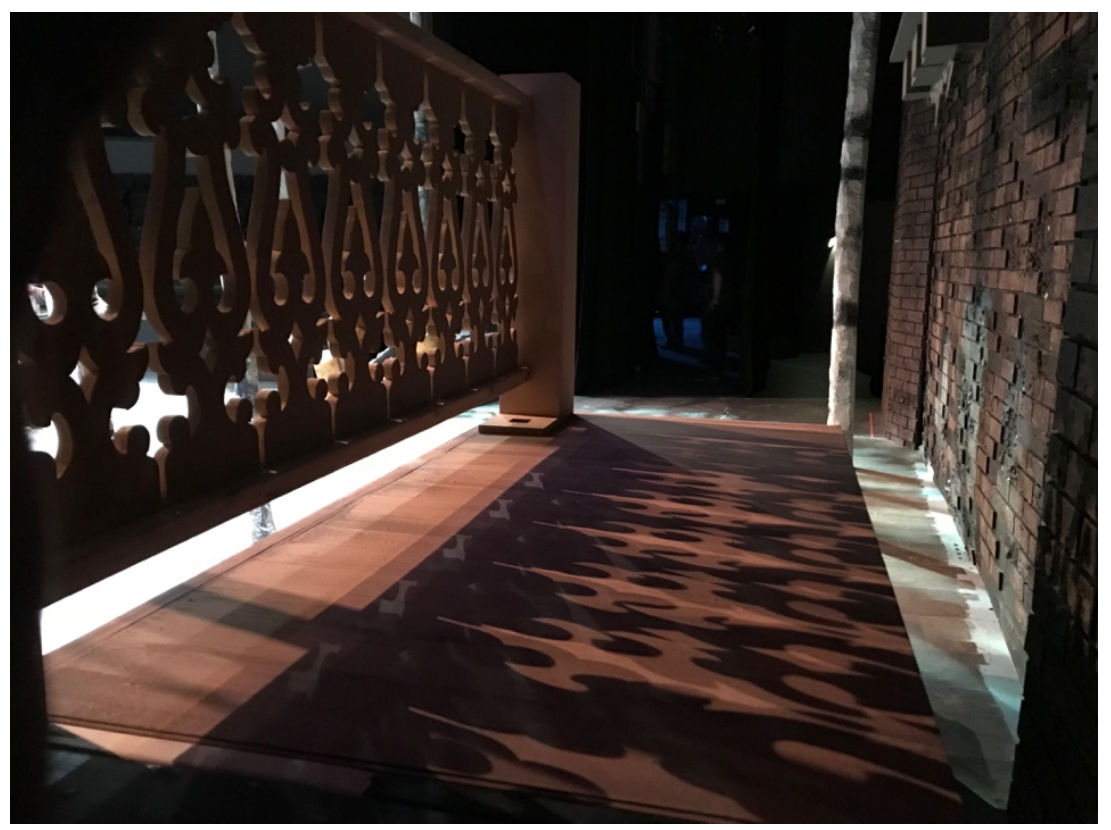

in a room and talk about the fire. I mean, that's funny in itself that he did that. The comedy that Chekhov uses is one that is based in the awkward, trivial happenings of everyday people. It was this exact reason that we were all a little apprehensive as to

Figure 11 Outside stairway to the backyard Act IV

whether the show would be accepted by non-theatre students. To our surprise, the show was actually accepted quite well. It was a relief to hear audiences getting the jokes and investing 
emotionally in the show every night. Each night I had to prepare emotionally to make sure that I was ready to live truthfully throughout the show. My preparation always consisted of focusing on the similarities between Vershinin and myself, and then allowing myself to live as me through the character every night.

When we first began rehearsing this show, Prof. McGonigle made it clear to everyone that when we arrived and entered the theater space, we were to leave everything else from our day out of it. We had an agreement as a cast to treat the play and the theater sacredly. Every night before the show, I would come down from the dressing room and sit in the space. I would think about the play, the relationships I had with each of the characters and how I felt as Vershinin about those relationships. I would think about my real family and the love I have for my own children. I would think of memories from my past; times when I felt like I needed something more than what I was getting. I would think of what it felt like when I first fell in love with my wife and the magic that surrounded my life at that time because of it. I would do all of this while experiencing the set. We were given such a rich environment to work in that it was amazing to be able to come in and live in the space before each performance to prepare as an actor.

What I found most challenging in the performance run of this show was where it fell in the school's season. We had a nine-day break in the middle of the run and it made it difficult to come back with excitement to finish the run. It all came together again though and I was thankful for the audience turnout we had at each show. Ultimately, as an actor, I grew being a part of this show. I was challenged every night to be in the moment and to try and be myself on stage. I'm proud of my performance, our cast, and our production team. It was a wonderful experience. 


\section{REFLECTIONS/CONCLUSION}

So many times we have to ask ourselves, "Why this play, now?" As I look back on this production, and the state of the world lately, I think this was a great show to highlight. This show speaks of the courage, resilience and strength women have shown throughout the years. Each of the sisters' fates in this show were somehow tied to a worldly perspective and system that only allowed men to hold the reigns and make decisions. These characters, although beaten down and left broken, make it clear at the end that they will continue in spite of the hand dealt to them. It took me a while to see this theme through the misfortunes in the story, but it makes me incredibly proud to have been a part of it.

The endurance of the human spirit is an amazing thing; the ability to press on through adversity and to triumph in the face of fear. I said it earlier, but I want to say it again: acting should make a person more empathetic. Acting should teach you what it's like to walk in someone else's shoes. Ultimately, acting should teach us to love more. I've been asked by many people before, "Why do you act?" Answering this question is always one of my biggest joys. I tell them, "Life is too short. As an actor, I get to live a thousand lives in a single lifetime."

I'm incredibly thankful for my time at WVU. As I approach the end of grad school, I find myself looking back on things a lot more fondly than I thought I would. Don't get me wrong; in the moment, some days of grad school were extremely tough. But I'm so privileged to have gotten the opportunity of being in this program. In three years I have been privileged to be a part of an ensemble. I've learned that talent isn't enough to make it in school as well as the industry. It comes down to hard work; a person's work ethic. I've learned to push through and finish more than I ever thought possible. 
The collaboration between an ensemble is such an amazing thing. Seeing the wonderful work that each part of a production team puts into a show to make it a reality is profoundly humbling. Thank you, West Virginia University. 


\section{BIBLIOGRAPHY}

Troyat, Henri. Daily Life in Russia under the Last Tsar. Stanford Univ. Press, 1989.

Chekhov, Anton Pavlovich. The Three Sisters. 1900.

Nafziger, Steven, and Tracy Dennison. "Micro-Perspectives on 19th-Century Russian Living Standards.” EconPapers, 8 July 2011, econpapers.repec.org/repec:wil:wileco:2007-07.

Bogart, Anne, and Tina Landau. The Viewpoints Book: a Practical Guide to Viewpoints and Composition. Theatre Communications Group, 2007.

"VCU Scholars Compass | Virginia Commonwealth University Research." Site, Josh Chenard, 2010, scholarscompass.vcu.edu/.

All photos taken by Rick Mugrage. 2018. 